\title{
aniki
}

Revista Portuguesa da Imagem em Movimento Portuguese Journal of the Moving Image

\section{O “cinema de garagem", provisoriamente: notas sobre o contexto de renovação do cinema brasileiro a partir da virada do século} Marcelo Ikeda ${ }^{1}$

\section{Introdução}

Algo de novo surgiu no cinema brasileiro por volta da virada deste século. Um conjunto de filmes de jovens realizadores começou a despontar com grande força inventiva, marcando a consolidação de um cinema não hegemônico, em nítido contraste com a típica cinematografia incentivada pelas políticas públicas do período. Inspirados pelos novos ventos, Dellani Lima e eu escrevemos uma publicação em regime de urgência que buscava reunir esses movimentos sob o termo "cinema de garagem" (Ikeda e Lima 2011). Em artigos posteriores, busquei desdobrar algumas das características desse cinema (Ikeda 2012, 2014).

O presente artigo apresenta em revista essa trajetória, retomando e ampliando alguns dos aspectos dos artigos anteriores com outros desdobramentos, ainda que com um tom sintético, dados os limites de sua extensão. O principal deles é esclarecer que o "cinema de garagem" não envolve apenas os filmes realizados nesse contexto, mas também as transformações na crítica e na curadoria, o que tornou possível a formação de um circuito, conferindo legitimidade a essas obras.

Buscaremos oferecer um amplo panorama desse contexto de transformações, abordando os movimentos de origem desse cenário de renovação, as relações orgânicas entre as mudanças nos modelos de produção, de crítica e de curadoria no período. Por fim, propomos o termo "cinema de garagem" para abranger esse circuito, ainda que com a ciência de suas fragilidades para reunir forças nitidamente heterogêneas.

\section{As leis de incentivo fiscal e o modelo hegemônico de financiamento}

No início dos anos 1990, o cinema brasileiro passou por uma abrupta descontinuidade. O presidente Fernando Collor de Mello ${ }^{2}$ provocou

\footnotetext{
${ }^{1}$ Universidade Federal do Ceará, Curso de Cinema e Audiovisual, Instituto de Cultura e Arte, 60165-110, Fortaleza, Brasil.

${ }^{2}$ Fernando Collor de Mello foi o primeiro presidente eleito pelo voto direto após o processo de redemocratização do Brasil. Tomou posse em 1990, mas permaneceu
} 
mudanças agudas na economia do país, guiadas por um ideário de base neoliberal, com uma forte reestruturação do Estado, iniciando um agudo movimento de privatizações ${ }^{3}$. No campo da cultura, o impacto foi acachapante. Por meio de um único decreto, as principais instituições públicas responsáveis pelo apoio ao cinema brasileiro foram extintas ${ }^{4}$, e o Ministério da Cultura foi transformado numa simples secretaria de governo (Catani 1994). Sem o apoio governamental, o mercado cinematográfico brasileiro foi completamente dominado pelo produto hegemônico estrangeiro. Em 1991 e em 1992, a participação do cinema brasileiro no mercado interno foi inferior a 1\% (Almeida e Butcher 2003).

Após as reações da sociedade civil e em meio ao processo de afastamento do presidente Collor, houve o restabelecimento de uma política estatal de estímulo à cultura, e também às produções cinematográficas. No entanto, enquanto nos anos 1970 e 1980, um órgão estatal robusto (a Embrafilme) atuava diretamente no mercado cinematográfico, produzindo e distribuindo os filmes brasileiros, em meados dos anos noventa, o modelo de intervenção estatal assumiu uma nova feição, com uma partilha de responsabilidades entre o Estado e o mercado (Lopes 2001). Com isso, desenvolveu-se uma política de incentivos fiscais, em que os projetos audiovisuais passaram a ser realizados a partir do aporte de recursos de pessoas físicas ou jurídicas, que abatem parcial ou integralmente esses recursos em suas respectivas declarações de imposto de renda. A Lei Rouanet (Lei $\mathrm{n}^{\circ}$ 8.313/91) e a Lei do Audiovisual (Lei $n^{0} 8.385 / 93$ ), com seus diversos aprimoramentos e alguns mecanismos de incentivo complementares, tornaram-se a base do apoio público à produção cinematográfica brasileira (Marson 2006). Construído sob uma perspectiva de desenvolvimento industrial, o modelo estimulava a aproximação de investidores privados, instigando a competitividade de obras realizadas por empresas produtoras, e visando ao seu retorno comercial.

Essas políticas apresentaram várias nuances e percalços ao longo das últimas duas décadas. Apesar de diretamente responsáveis pelo processo da chamada "retomada do cinema brasileiro", não lograram plenamente os seus objetivos, por motivos que escapam ao objetivo deste artigo ${ }^{5}$. De qualquer forma, com esse modelo de financiamento, eram naturalmente privilegiadas obras com maior

na presidência apenas até dezembro de 1992, renunciando ao cargo pouco tempo antes de ter sido condenado pelo Senado Federal por crime de responsabilidade, o que provocou seu impeachment.

${ }^{3}$ Sobre o neoliberalismo no Governo Collor, ver, entre outros, Alcoforado 1998 e Antunes 2004.

${ }^{4}$ São elas: a Empresa Brasileira de Filmes (Embrafilme), o Conselho Nacional do Cinema (Concine) e a Fundação do Cinema Brasileiro (FCB). A esse respeito, ver Ikeda 2015.

${ }^{5}$ Esses motivos podem ser encontrados em estudos como os de Ikeda 2015; Bahia 2009; Gatti 2005. 
expectativa de retorno comercial, favorecendo-se o processo de captação de recursos, e despertando o interesse dos gerentes de marketing das empresas privadas, que viam no aporte de recursos uma oportunidade de exposição de suas marcas.

Dessa forma, os caminhos para que um cineasta pudesse realizar seu primeiro longa-metragem eram bastante restritos. A captação de recursos para projetos com pouco apelo comercial era naturalmente lenta, e ainda mais difícil por se tratar de realizadores estreantes. Esse processo fez com que diversos realizadores extremamente talentosos demorassem mais de dez anos para que pudessem finalmente realizar seu primeiro longa-metragem, mesmo com diversos prêmios como curta-metragistas no currículo, como Gustavo Spolidoro, Paulo Halm, Eduardo Nunes, Camilo Cavalcante e Kleber Mendonça Filho. A maior parte desses realizadores apenas conseguiu realizar seu primeiro longa por meio de um edital específico do Ministério da Cultura, direcionado a filmes de baixo orçamento. Ou seja, com recursos diretos do Ministério, e não por meio das leis de incentivo fiscal. Mas, como esse edital premiava apenas poucos projetos por edição, agravado pelo fato de ter uma realização esporádica, a concorrência pelos recursos desse edital era extremamente acirrada.

$\mathrm{Ou}$ seja, de um lado as leis de incentivo fiscal foram responsáveis pelo chamado processo de "retomada do cinema brasileiro", recobrando a produção cinematográfica nacional do "coma induzido" pelo governo Collor. Por meio desse modelo de financiamento, foram produzidas obras seminais como Central do Brasil (Walter Salles, 1998), Cidade de Deus (Fernando Meirelles e Kátia Lund, 2002), e Tropa de elite (José Padilha, 2007), que, entre outros filmes, projetaram o cinema brasileiro no exterior, por meio de sua participação em festivais internacionais de prestígio como o de Cannes, Veneza ou Berlim (Selonk 2004). No entanto, por outro lado, as leis de incentivo não conseguiam viabilizar um conjunto de projetos mais autorais, que nem atraíam o interesse de investidores privados, nem se enquadravam no perfil dos editais públicos. Jovens realizadores com projetos mais arriscados não conseguiam se inserir na política oficial de financiamento.

\section{Novos modos de produção e de difusão do audiovisual}

Em paralelo ao modelo hegemônico de produção e de financiamento às obras cinematográficas, surgiram, paulatinamente, a partir deste século, alternativas para o campo do audiovisual. Essas mudanças podem ser relacionadas a um movimento inicial, de âmbito tecnológico. A ampla disseminação do digital produziu impacto não apenas na produção de novas obras, mas também para a circulação das mesmas, contribuindo para a formação de novas redes e circuitos. 
Quanto à produção, o digital permitiu a realização de obras em vídeo mais baratas e com produção mais ágil. O vídeo já existia no Brasil desde os anos 1970, quando os artistas visuais começaram a trabalhar com os primeiros modelos das câmeras portapak, mas as tecnologias digitais, introduzidas no Brasil a partir de meados dos anos 1990, trouxeram uma nova visibilidade para o formato, a partir dos modelos das câmeras miniDV (Machado 2003). Com um custo bastante reduzido em relação aos equipamentos de vídeo utilizados para broadcast, o vídeo se tornou acessível para o realizador independente, e não mais apenas para grandes empresas ou instituições, que operavam em larga escala. Além do mais, a tecnologia de compressão de dados, típica dos formatos digitais, tornou o sinal de vídeo dessas câmeras cada vez mais robusto. As novas câmeras, além de mais baratas, eram mais sensíveis à luz e mais leves. Em complemento aos novos modelos de câmera, os equipamentos acessórios tornaram-se mais acessíveis. Da mesma forma, a edição e finalização dos vídeos era possível em computadores pessoais, e não mais em grandes ilhas de edição, com equipamentos específicos ou computadores de grande porte.

Além das facilidades de produção e de operação, o vídeo digital permitiu que as obras pudessem ser produzidas mediante outro arranjo de produção. Tornava-se possível, por exemplo, realizar um vídeo sem funções técnicas definidas, ou, ainda, que todo o processo fosse mais flexível. Com o vídeo, o financiamento público deixou de ser a única possibilidade para a produção de filmes no país. O abismo entre $\mathrm{o}$ amador e $\mathrm{o}$ profissional havia consideravelmente se reduzido, já que se tornava possível para um realizador independente realizar uma obra audiovisual de bom acabamento técnico sem um investimento inicial elevado em infraestrutura técnica.

Com o tempo, essa cena foi amadurecendo e se diversificando, irradiada em rede em diversos cantos do país. Mais filmes foram sendo feitos, sem financiamento estatal, com uma estrutura colaborativa e modos de produção mais flexíveis. Estava se desenvolvendo um cinema que acreditava na precariedade como potência e lidava com o processo, e não necessariamente o produto final, como um dos pontos-chave de uma nova forma de produção, menos hierarquizada e mais flexível, dialogando com o documentário e com a videoarte, que via uma relação de cumplicidade entre o cinema e o mundo, entre a criação e a vida. Dos primeiros curtas-metragens em vídeo, foi crescendo a certeza de que era possível realizar longas-metragens com o mesmo espírito criativo, com o mesmo modo de produção. O tabu do "primeiro longa" foi reduzido: a partir de meados dos anos 2000, um conjunto de expressivos longas-metragens foi realizado completamente sem recursos públicos ou com orçamentos inferiores a $\mathrm{R} \$ 300 \mathrm{mil}$, com grande repercussão crítica nacional e com participação em grandes 
festivais internacionais, como Locarno e Roterdã ${ }^{6}$. Coletivos cinematográficos como a Teia (MG), Alumbramento (CE), Filmes a Granel (PB), Símio Filmes (PE), Filmes de Plástico (MG), Caboré (RN), Coletivo Urgente de Audiovisual - CUAL (BA), entre vários outros, são exemplos de arranjos produtivos inovadores, pautados pela coletividade e pela desierarquização dos processos de realização audiovisual.

\section{A formação de um circuito, entre a produção, a curadoria e a crítica}

A partir das possibilidades oferecidas pela maior difusão das tecnologias digitais, o contexto da produção de obras audiovisuais ampliou-se consideravelmente. Tornava-se possível produzir, em maior escala, filmes que escapavam do modelo hegemônico de financiamento: o edital público ou as leis de incentivo fiscal.

É preciso compreender o avanço dessa geração não apenas quanto a novas possibilidades de produção de obras audiovisuais, mas quanto ao modo como essa geração se consolidou mediante a formação de um novo circuito, entrelaçando a realização com a crítica e as mostras e festivais de cinema. A formação desse circuito conferiu legitimidade ao percurso desses jovens realizadores. Assim como surgiram as bases para uma produção não hegemônica, houve um gesto correlato de surgimento de novos festivais de cinema e espaços para a crítica cinematográfica.

Num momento inicial, no início dos anos 2000, os vídeos produzidos sob os novos arranjos de produção não conseguiam ser exibidos nos circuitos de maior visibilidade. Ainda que os festivais de cinema tenham surgido no país a partir dos anos 1960, como os pioneiros Festival de Brasília do Cinema Brasileiro (DF, 1965) e Festival de Cinema de Gramado (RS, 1973), é possível afirmar que os festivais de cinema se expandiram no Brasil especialmente a partir da década de 1990, como resposta de resistência a um cenário de restrição para o cinema brasileiro, com o fim dos apoios governamentais do governo Collor e com o contínuo fechamento de salas de exibição em todo o país. Na década de 1990, surgiram festivais como o Festival de Cinema de Natal (RN, 1991), Cine Ceará (CE, 1991), Festival de Cinema de Cuiabá (MT, 1993), Vitória Cine Vídeo (ES, 1994), Cine PE (PE, 1997), FAM - Florianópolis

\footnotetext{
${ }^{6}$ Entre eles, podemos citar: Acidente (Pablo Lobato e Cao Guimarães, 2006), Meu Nome é Dindi (Bruno Safadi, 2007), Sábado à Noite (Ivo Lopes Araújo, 2007), Pacific (Marcelo Pedroso, 2009), A Fuga da Mulher Gorila (Felipe Bragança e Marina Meliande, 2009), Um Lugar ao Sol e Avenida Brasília Formosa (Gabriel Mascaro, 2009 e 2010), A Casa de Sandro e Chantal Akerman, de Cá (Gustavo Beck, 2009 e 2010), Estrada Para Ythaca (Guto Parente, Luiz e Ricardo Pretti, e Pedro Diógenes, 2010), O céu sobre os ombros (Sérgio Borges, 2010).
} 
Audiovisual Mercosul (SC, 1997), entre diversos outros (Leal e Mattos 2006).

Tendo em vista o cenário restritivo para o audiovisual brasileiro, como abordamos na introdução deste artigo, os festivais de cinema passaram a exercer o papel de salvaguarda da produção nacional, como forma de diálogo com a sociedade da importância cultural da sobrevivência do cinema brasileiro. Dessa forma, acabaram tornando-se sustentáculos de um circuito de legitimação da produção hegemônica: era preciso mostrar à sociedade de que o cinema brasileiro precisava continuar a existir, como sinal da afirmação da identidade nacional e da riqueza da produção cultural brasileira, e que se vivia num momento de profissionalização da produção cinematográfica brasileira. Ou seja, os festivais acabavam sendo a expressão de um cinema brasileiro oficial, que, ainda traumatizado pelos atos da Era Collor, buscava sobreviver, precisando se defender das acusações dos fantasmas do passado, como o mau uso dos recursos públicos (como fantasma da Embrafilme) ou a vulgarização de seus temas (a pornochanchada ${ }^{7}$ ). Os mesmos valores de "bom gosto", "utilidade", "relevância cultural" e "profissionalismo" que nortearam as leis de incentivo acabaram ressoando para as escolhas das curadorias dos principais festivais de cinema do período. Os festivais eram o estágio perfeito de legitimação de um "cinema de qualidade", que buscava sua reconciliação com o mercado e com o público.

Um dos aspectos dessa questão era a própria bitola de produção das obras. Os festivais privilegiavam os filmes finalizados em película $35 \mathrm{~mm}$ que, além de ser o padrão adotado no mercado de exibição cinematográfica, aliava qualidade técnica e profissionalismo, já que eram produzidos e realizados por uma estrutura de produção nitidamente mais robusta. Os principais festivais de cinema do período somente exibiam longas-metragens finalizados em película $35 \mathrm{~mm}$. Quanto aos curtas-metragens, existia a separação de sessões segundo a bitola das obras. As sessões em $35 \mathrm{~mm}$ geralmente acompanhavam os longas-metragens, que eram a atração principal no cardápio de opções do evento. Os curtas em $16 \mathrm{~mm}$ e em vídeo eram exibidos separadamente, muitas vezes em espaços de projeção e em horários nitidamente alternativos, tornando clara uma forma de hierarquia entre as obras segundo sua bitola de produção.

\footnotetext{
${ }^{7}$ A pornochanchada foi um gênero do cinema brasileiro, muito popular nos anos 1970, relacionado a comédias de apelo erótico. Em sua época, muitos críticos rotularam o gênero como mero escoadouro de obras vulgares, apelativas e grosseiras, mas nos últimos anos uma nova geração de críticos vem revalorizando o gênero, destacando o valor inventivo de realizadores como Ody Fraga, Jean Garret, Claudio Cunha, entre outros. A esse respeito, ver Abreu 2006 e Simões 2007.
} 
Se no início dos anos 2000 houve um exponencial aumento da produção audiovisual em vídeo, havia um gargalo para sua exibição, já que os festivais de cinema privilegiavam as obras em película cinematográfica. A crescente profusão do vídeo acabou naturalmente levando à busca de novos espaços de exibição, que pudessem refletir a variedade das novas formas de produção.

A principal forma de escoamento dessa produção seriam os cineclubes, que, no início dos anos 2000, começaram a ter um aumento expressivo. O cineclubismo acabou assumindo uma função não apenas de exibição dessas obras, mas de um ponto de encontro que contribuiu espontaneamente para a consolidação de uma cena audiovisual. Muitos desses eventos tinham como principal papel não diretamente a formação de público para o consumo audiovisual, mas o estreitamento de laços de identidade de artistas que desejavam se engajar mais profundamente no contexto da realização audiovisual. Ou seja, mais que exibir filmes, os cineclubes geravam encontros, a partir da consolidação de trocas afetivas, que permitiam que artistas de diferentes formações conhecessem seus pares para, a partir daí, realizarem futuros projetos. Esboçava-se, então, a formação de um circuito, movido primordialmente pelo desejo de experimentação das possibilidades do audiovisual como forma de expressão e mesmo de sociabilidade, em nítido contraste com a estratégia da formação de um portfolio para elaboração de produtos comerciais competitivos, sob as regras de negócio do mercado audiovisual. A partir dos cineclubes, identificou-se a possibilidade de expandir o raio de ação dessas pequenas sementes, para eventos mais estruturados, que pudessem fornecer maior visibilidade a essas produções.

Nesse contexto de transformações, houve a primeira edição da Mostra do Filme Livre (MFL), no Centro Cultural Banco do Brasil $^{8}$, no Rio de Janeiro, em janeiro de 2002. Trata-se da primeira mostra dedicada primordialmente ao cinema brasileiro, com funcionamento e estrutura regulares, que exibiu, na mesma sessão, filmes de diferentes bitolas. A MFL ofereceu um espaço para as novas obras audiovisuais que eram produzidas nesse novo contexto e que não conseguiam abrigo nos festivais de cinema do país, que, como dissemos antes, ainda estavam voltados para outra lógica de circulação.

A MFL surgiu como derivação do próprio movimento cineclubista no Rio de Janeiro. Guilherme Whitaker, idealizador da

\footnotetext{
${ }^{8}$ Todas as edições da Mostra do Filme Livre (MFL) foram realizadas no Centro Cultural Banco do Brasil (CCBB). Em sua primeira edição, em 2002, a MFL foi realizada apenas na sede do Rio de Janeiro (RJ). A partir de sua $10^{\mathrm{a}}$ edição, a MFL expandiu-se para o CCBB de São Paulo (SP). No ano seguinte, passou a ser também realizada no CCBB de Brasília (DF). A partir de 2015, a MFL passou a ser exibida em todas as sedes do CCBB no Brasil, ocupando igualmente o CCBB de Belo Horizonte (MG).
} 
mostra, assim como vários de seus curadores nos anos iniciais, como Pedro Bronz, Chico Serra, Karen Akerman, Rodrigo Savastano e eu mesmo, aproximamo-nos nas sessões cineclubistas, em especial do cineclube Mostra o que neguinho tá fazendo, com sessões mensais na Fundição Progresso, no bairro da Lapa, a partir de 1999 (Whitaker 2011). Com uma forte defesa do Super-8mm e dos formatos artesanais de produção, o cineclube tornou-se um importante ponto de encontro da cena independente carioca. A MFL potencializou esse gesto, recebendo obras audiovisuais de todo o país.

Ao longo dos anos, o circuito dos festivais foi amadurecendo, contribuindo decisivamente para um maior debate crítico, e conferindo visibilidade a essa produção. Entre outros, pode citar-se a Mostra de Cinema de Tiradentes (MG, primeiro evento em 1997), Panorama Coisa de Cinema (BA, 2002), CineEsquemaNovo (RS, 2003), Janela de Cinema (PE, 2008), Semana dos Realizadores (RJ, 2009), e Olhar de Cinema (PR, 2012) 9

Em analogia à formação de novos circuitos de circulação dessas obras, em cineclubes ou em novos festivais de cinema, houve um movimento de renovação na escrita da crítica cinematográfica. Para isso, é importante compreender os movimentos de transformação na cinefilia, ocorridos em decorrência da formação das redes com a difusão da Internet. No início dos anos 1990, apenas era possível ter acesso ao cinema contemporâneo por meio do circuito exibidor (salas de exibição) ou pelas mostras internacionais de cinema. No entanto, o circuito exibidor encontrava-se em um contexto de mudanças, com a formação de um novo paradigma de exibição coletiva, com a introdução dos multiplexes, e privilegiava blockbusters e filmes de distribuição nassiva. Tornava-se possível assistir a outros cinemas somente em salas públicas ou no circuito do "cinema de arte", como nas redes do Grupo Estação (RJ) ou no Espaço de Cinema (SP). Esses mesmos circuitos eram responsáveis pelas duas mais importantes mostras internacionais de cinema - o Festival do Rio (RJ) e a Mostra Internacional de Cinema de São Paulo (SP) -, que permitiam que os cinéfilos brasileiros travassem contato com a parcela mais inventiva da produção contemporânea mundial.

No entanto, a difusão das tecnologias peer-to-peer (p2p) alterou esse panorama, tornando possível o acesso a filmes, além desse pequeno circuito. Além de filmes, houve o contato com livros e periódicos que discutiam criticamente a produção de novos

\footnotetext{
${ }^{9}$ Outros locais poderiam ser citados, como os eventos realizados na Cinemateca do Museu de Arte Moderna (MAM/RJ), a Cinemateca Brasileira (SP) e centros culturais como o já citado Centro Cultural Banco do Brasil, com um relevante papel de ampliação do circuito cinéfilo. No entanto, os festivais e mostras de cinema citados no corpo do texto revelam-se pontos nodais, visto que se dedicaram primordialmente à exibição de obras brasileiras pouco exibidas em outros contextos.
} 
realizadores do cinema contemporâneo na virada do século. A própria experiência da cinefilia foi transformada pelas mudanças desse contexto, gerando o que autores chamaram de uma cibercinefilia (Rosenbaum e Martin 2003; Prysthon 2013). É importante assinalar que realizadores de fundamental contribuição para o cinema contemporâneo, como Claire Denis, Hou Hsiao Hsien, Pedro Costa, Carlos Reygadas, Lisandro Alonso, Naomi Kawase permaneceram inéditos no circuito exibidor brasileiro durante muitos anos. Por meio da Internet, tornou-se possível para os cinéfilos brasileiros terem acesso a essas obras.

Se o cinema hegemônico brasileiro procurava na grande mídia - televisão, jornais e revistas - a principal forma de divulgação das obras audiovisuais, surgia uma jovem geração que buscava expressar seu espanto diante do acesso a outras obras audiovisuais, fora do circuito hegemônico de circulação, que não conferia espaço a essas produções. Surgia, portanto, uma "nova crítica de cinema", cujos textos se espraiavam em sites e blogs pela Internet. Dois desses veículos cumpriram importante contribuição no sentido de difundir as estéticas do cinema contemporâneo mundial e brasileiro: a Contracampo (1998) e, posteriormente, a Cinética (2006). Mas além dessas, outros sites, como a Filmes Polvo, Interlúdio, Revista Foco ou a Cinequanon ${ }^{10}$ podem ser integrados a esse grupo de ampliação das formas de expressão da crítica cinematográfica na Internet, a partir da virada do século (C Nogueira 2006).

A nova crítica de cinema estimulou um ambiente propício para amadurecer uma reflexão sobre novas possibilidades estéticas para o cinema brasileiro, que melhor dialogassem com os novos conceitos de dramaturgia surgidos no cinema contemporâneo, conforme exibidos nos principais festivais do mundo. Assim, houve um paralelo entre o amadurecimento de uma nova geração de críticos de cinema e o surgimento de curadores nesse novo circuito de festivais. Críticos como Eduardo Valente, da Contracampo, e Cleber Eduardo, da Cinética, tornaram-se, por exemplo, curadores da Mostra de Cinema de Tiradentes.

Essas transformações estimularam a formação de novos circuitos, com a aproximação entre realizadores, críticos e curadores. Muitos dos novos festivais de cinema surgidos nesse período foram idealizados e organizados por realizadores. Esses projetos frequentemente surgiam, portanto, como um desejo dos realizadores de promover diálogos entre estéticas e modelos de produção, e como estratégia de consolidação de uma rede simbólica em que esses filmes poderiam circular, para além do circuito mais

\footnotetext{
${ }^{10}$ Contracampo (www.contracampo.com.br, 1998), Cinética (www.revistacinetica.com.br, 2006), Cinequanon (www.cinequanon.art.br, 2005), Filmes Polvo (http://www.filmespolvo.com.br/, 2007), Foco (http://focorevistadecinema.com.br/, 2009), Interludio (http://www.revistainterludio.com.br/, 2011).
} 
tradicional dos festivais já estabelecidos. Realizadores como Gustavo Spolidoro (CineEsquemaNovo/RS), Claudio Marques e Marilia Hughes (Panorama/BA), Aly Muritiba (Olhar de Cinema/PR) e Kleber Mendonça Filho (Janela do Cinema/PE) foram atores fundamentais para o surgimento dessa rede.

Criada em 2009, a Semana dos Realizadores funciona como importante ponto de destaque para essa nova produção. Sua formação se estruturou a partir de uma comissão de sete membros, com um caráter híbrido entre realizadores, críticos e curadores (Eduardo Valente, Felipe Bragança, Gustavo Spolidoro, Helvécio Marins Jr., Kléber Mendonça Filho, Lis Kogan e Marina Meliande). Na carta de fundação (Valente et alii 2009), a comissão ressalta que a mostra surge como desejo de ser "alternativa e complementar" à curadoria do Festival do Rio, principal festival de cinema de sua cidade (o Rio de Janeiro). Assumindo-se aos moldes da "Quinzena dos Realizadores" do Festival de Cannes, a Semana dos Realizadores surge para "conhecer e ver aquilo que a Premiére Brasil não nos deixará ver do cinema brasileiro a partir da semana seguinte à sua realização". Estabelecendo seu ideário a partir de uma "carta de fundação", a criação da Semana surge claramente como contraponto ao Festival do Rio, engajando-se, portanto, na afirmação simbólica de um circuito não hegemônico.

$\mathrm{Na}$ cidade de Recife, o Janela Internacional de Cinema, idealizado pelo crítico e realizador Kleber Mendonça Filho, era o espaço para a exibição dos novos realizadores audiovisuais brasileiros. As tensões com o mais tradicional festival de cinema da cidade, o Cine $\mathrm{PE}$, se evidenciaram na cerimônia de premiação no encerramento da edição do Cine PE de 2011, quando um conjunto de realizadores subiu ao palco e estendeu uma faixa com os dizeres "menos glamour, mais cinema”. A nova geração de realizadores pernambucanos não se sentia representada nos valores estéticos que norteavam o evento (Almeida e Mendonça 2012).

\section{$\mathrm{O}$ "cinema de garagem": em busca de um conceito provisório e perecível}

Em janeiro de 2011, na Mostra de Tiradentes, o curador e realizador Dellani Lima e eu lançamos o livro Cinema de Garagem - um inventário afetivo sobre o jovem cinema brasileiro do século XXI (Ikeda e Lima 2011). Trata-se da primeira publicação a lançar um olhar crítico e panorâmico sobre o movimento de renovação do cinema brasileiro, investigando os novos modos de fazer que se contrapõem ao típico cinema brasileiro da "retomada". Esse livro foi motivado pela boa repercussão de filmes da safra de 2010. De fato, o ano de 2010 foi um ano-chave nesse movimento, cristalizado em dois momentos: a participação de A alegria (Felipe Bragança e Marina Meliande, 2010), na Quinzena dos Realizadores, evento paralelo ao 
Festival de Cannes, e as premiações de melhor filme e direção para $O$ céu sobre os ombros (Sérgio Borges, 2010) no $43^{\circ}$ Festival de Brasília do Cinema Brasileiro. Ou seja, de um lado, com a presença no mais prestigiado festival internacional de cinema e, de outro, recebendo os principais prêmios no mais tradicional festival de cinema no Brasil. Ainda que a nova geração contasse com um circuito de novos festivais de cinema e novos veículos de crítica cinematográfica, a presença em festivais de cinema hegemônicos ainda se revelava fundamental para legitimar a trajetória dessa geração.

Evidentemente, a publicação não tinha a pretensão de esgotar as referências à miríade de realizadores, filmes, tendências e características que surgiram nesse período, mas apenas apontar exemplos de vitalidade dessa produção. Era importante mostrar que, se os festivais nacionais e internacionais começavam a reconhecer o amadurecimento dessa cena, esses eram na verdade os frutos de um processo que durava pelo menos dez anos. O livro era um trabalho emergencial, perecível, mas que tinha o mérito de reunir algumas características em comum de uma nova geração no cinema brasileiro, que apontava para um caminho de renovação. Para isso, cunhamos o termo "cinema de garagem".

Após o lançamento do livro, muitos dos leitores nos indagavam como seria possível ter acesso a esses filmes. Desse modo, idealizamos a Mostra Cinema de Garagem, realizada na Caixa Cultural Rio de Janeiro, em julho de $2012^{11}$. Com duração de duas semanas, em duas salas de exibição, foram exibidos 25 longas e 24 curtas-metragens. Era um número bastante razoável de obras, fosse para compor um panorama das possibilidades estilísticas dessa geração, fosse para afirmar sua plena existência para além de um pequeno grupo fechado. Se no primeiro livro (o de 2011) oferecemos nossa visão do que seria o "cinema de garagem", achamos agora importante abrir essa discussão. Assim, além da exibição dos filmes, a Mostra incluiu seis debates, com a presença de realizadores, críticos e curadores, como Bruno Safadi, Ricardo Pretti, Eduardo Valente, Lis Kogan, Silvio Da-Rin, Daniel Caetano, Sérgio Borges, entre outros, além da publicação de novo livro (Ikeda e Lima 2012), com uma coletânea de artigos escritos por críticos e pesquisadores de formação diversa, como Carlos Alberto Mattos, Denilson Lopes, Arthur Tuoto, Bruno Andrade, Camila Vieira e Marcelo Miranda.

Em 2014, organizamos uma nova mostra de cinema, agora realizada em duas cidades: Fortaleza (no Centro Cultural Dragão do Mar) e Rio de Janeiro (no Centro Cultural da Justiça Federal), exibindo nove longas-metragens, com debates com a presença de

\footnotetext{
${ }^{11}$ Toda a programação da Mostra, assim como o áudio dos debates e o livrocatálogo com artigos sobre essa produção, encontra-se ainda disponível em http://www.cinemadegaragem.com/2012/apresentacao.html
} 
realizadores e críticos, e publicamos novo livro (Ikeda e Lima 2014). $\mathrm{Na}$ edição de Fortaleza, entre outros convidados, estavam Andrea Tonacci, Adirley Queirós e o ator-crítico Jean-Claude Bernardet ${ }^{12}$.

Compreendemos que o termo "cinema de garagem" é provisório e perecível, que dialoga com o gesto dos próprios filmes. Entendemos suas diversas limitações, mas ainda assim o defendemos como meio de iniciar um debate sobre a "identidade-na-diferença" dessa geração. Ainda que o conjunto de obras seja naturalmente difuso e heterogêneo, entendemos que há uma base em comum que permite reuni-los como parte de uma tendência, que aponta, de forma sistemática, para possibilidades de renovação dos modos de ser do cinema brasileiro a partir deste século.

O próprio termo carrega consigo suas contradições. De um lado, com o termo "cinema". Acreditamos que se faz cinema independentemente da bitola. São todos filmes, apesar de serem, quase todos, gravados ou finalizados em vídeo. Com os novos processos digitais, de hibridização dos formatos, acreditamos que a definição a partir das bitolas perdeu sua importância central. Com a digitalização do processo de produção e também de projeção cinematográfica, consideramos que o termo "cinema" não se relaciona com o suporte físico de produção ou de finalização da obra, mas primordialmente com seu circuito de exibição. Assim, concentramo-nos nas obras audiovisuais que buscam a sala de exibição como seu circuito prioritário de exibição, excluindo da análise outros tipos de obras e de circuitos, como as obras audiovisuais expandidas, para exibição em galerias e museus, bem como as obras destinadas prioritariamente a outros segmentos de mercado, como a televisão ou a Internet.

De outro, a expressão "de garagem". Com ela, queremos apontar para outros modos de produção para além do "cinema industrial". Com a acessibilidade das novas tecnologias digitais, é possível, com uma câmera portátil e com software de edição, fazer e montar filmes em nosssas próprias casas, nas nossas próprias garagens. Há um paralelo com a explosão do cenário da música independente, de que Dellani Lima também faz parte, e suas "bandas de garagem". Esse termo também problematiza as fronteiras entre o "amador" e o "profissional", que cada vez estão mais tênues. Essas diferenças não estão tão propriamente marcadas no campo da técnica (a acessibilidade dos meios de produção) mas sobretudo por uma postura ética do artista, que volta sua produção primordialmente não para o mercado (para o reconhecimento artístico ou para a renda de bilheteria) mas para uma vocação de expressão mais propriamente pessoal.

\footnotetext{
${ }^{12}$ A programação da Mostra nas duas cidades, assim como livro, está disponível em http://www.cinemadegaragem.com/2014/
} 
As mudanças puderam ser vistas não apenas com a introdução do digital, mas nos modos de produção: formas colaborativas, com coletivos cinematográficos, com a formação de redes ligando artistas em diversos pontos do país. Mas com o termo "de garagem” não queremos apenas apontar para uma questão de custos, para o barateamento dos equipamentos de produção ou para as possibilidades de uma produção de amadores (como, por exemplo, no "cinema de bordas"13). A questão econômica - a relação dos custos de financiamento e sua inserção no mercado audiovisual - é, sem sombra de dúvidas, um aspecto crucial dessa questão mas não é a única, e talvez não seja a mais essencial. Buscamos, também, falar de possibilidades estéticas, éticas e políticas que surgiram a partir dessas novas possibilidades. De uma outra forma de estar no mundo, de se conectar com o mundo a partir do audiovisual.

Por isso, muitas vezes é difícil delimitar com precisão as fronteiras que circunscrevem esse cinema. "Cinema de Garagem" é um termo provisório, assim como também o eram, em suas respectivas épocas, termos como "nouvelle vague", "neorrealismo italiano" ou "cinema novo". O que propomos é que, acima de tudo, este seja um "ponto de partida" para refletir sobre as transformações no cinema brasileiro a partir deste século. Pensar o que aproxima e o que distancia certos filmes, certos realizadores, certos contextos. Pensar na possibilidade de efetuar recortes, sejam estéticos, geográficos, ou políticos. Pensar na formação de um circuito que confere legitimidade a esses autores, mediante uma articulação entre produção, crítica e curadoria. Interessa-nos mais alimentar essa discussão do que delimitar fronteiras ou estabelecer uma taxonomia estrita.

É possível conjecturar que esses arranjos ocorreram em períodos anteriores da trajetória do cinema brasileiro, possuindo paralelos com os "ciclos regionais" ou mesmo com o "cinema marginal brasileiro". No entanto, ainda que não reivindique o completo ineditismo da geração de garagem, busco apontar para outras configurações desse contexto, em especial para a formação de um circuito, que envolve uma articulação programática entre realizadores, críticos e curadores.

No já citado catálogo-livro da Mostra Cinema de Garagem realizada em 2012, propus uma tentativa de definição do termo a partir de quatro eixos que se complementam: aspectos econômicos, estéticos, éticos e políticos. Aqui, buscarei, de forma bastante sintética, exprimir a natureza desses eixos, que pretendo desenvolver melhor em outros artigos.

\footnotetext{
${ }^{13}$ Conforme Lyra (2009), o "cinema de bordas é produzido por realizadores autodidatas, moradores de cidades pequenas ou de arredores das grandes capitais." Realizado de forma amadora, dialoga com o modo de vida e o imaginário popular massivo das regiões onde foram produzidos, visando primordialmente ao entretenimento. Ver também Lyra e Santanna (2006).
} 
Quanto aos aspectos econômicos, buscamos apontar para um cinema que não visa primordialmente sua inserção no mercado como mero produto ou commodity, por meio de uma aproximação com agentes hegemônicos internacionais (as majors) ou locais (no caso brasileiro, o Grupo Globo). Vivenciamos, na sociedade contemporânea, um acirramento dos processos de concentração econômica, estimulado pelos movimentos de fusão e conglomeração, de modo que as empresas muitas vezes são maiores que as nações (Moraes 2006; Santos 2000). Num processo de resistência à padronização e à massificação do consumo dos bens culturais, buscamos destacar uma produção periférica (Prysthon 2002) que sobrevive propondo outras formas de ocupar os mercados, por meio de uma distribuição e circulação alternativas, ou visando "nichos de mercado". Ou ainda um cinema que procure subverter as noções tradicionais de produção e de circulação de bens, ou, nos termos de Migliorin (2011), um "cinema pós-industrial". O "cinema de garagem" brasileiro procurou formas alternativas de financiamento para além do modelo hegemônico baseado nas políticas públicas promovidas pela ANCINE, com base nas leis de incentivo fiscal. Além disso, buscou outras formas de circulação, para além da mais típica estrutura dos segmentos de mercado cinematográfico, ou simplesmente negou a conexão com o mercado como forma de dar visibilidade às obras produzidas.

Quanto aos aspectos estéticos, procuramos investigar as características de um cinema que escapa dos padrões hegemônicos do cinema clássico narrativo, buscando outras vias de expressão que se aproxime das estéticas contemporâneas. Um "cinema de fluxo", nos termos de Oliveira Jr. (2013), que propõe um tipo de dramaturgia não diretamente herdeira dos modos de narrar histórias, como os romances do século XIX (Bordwell 2005), mas que promove um alargamento das noções de percepção, colocando em crise a mise en scène clássica, baseada no equilíbrio, na clareza, no cinema de decupagem. Obras menos centradas na narrativa e na psicologia como molas propulsoras, mas mais fluidas, voltando-se para o sensório, para o fluxo dos corpos (Shaviro 1993; Bezerra 2010), ou ainda, para o cinema como fenômeno, em que o acaso, o irrepetível e o indescritível dominam a cena.

Nesse contexto, percebemos a marcante presença do documentário, ou ainda, de um modo de inscrição do real, ainda que afirme a presença de uma escritura fílmica com aspectos ficcionais, de modo que passam a ser borradas ou indiscerníveis as fronteiras entre o que existe previamente à presença da câmera e o que a câmera inscreve quando é disparada. O cinema contemporâneo resgata uma revalorização do real, mas sem a inocência da busca por uma "verdade" ou uma "pureza" - antes compreendendo seus riscos (Commoli 2005) e suas fissuras, provocando outros modelos de representação (Nichols 2008). São diversos os modos como o real se 
inscreve em um conjunto de filmes brasileiros recentes, dialogando com uma extensa bibliografia que reflete sobre as questões do documentário no cinema brasileiro contemporâneo, como nos trabalhos de Lins e Mesquita 2008, Migliorin 2010, Feldman 2012, entre outros.

$\mathrm{O}$ alargamento do conceito de mise en scène permite a aproximação de modelos híbridos de narrativa, com a marcante presença da simbiose entre outras manifestações artísticas, como as artes visuais, o teatro, a dança, a performance, entre outras. Nesse contexto, também ganham relevo as escritas de si, a autobiografia e a auto-mise en scène como proposta fílmica, bem como os filmesdiários e filmes-carta (Klinger 2006; Costa 2009). Ou ainda os filmesensaio e a presença do filme-de-arquivo, do found footage (Vieira Jr. 2011), ou ainda de "imagens-ruína" (Azevedo 2014).

Esses processos também produzem efeitos nos próprios modos como as obras foram realizadas. Os modos de fazer também sugerem e fornecem implicações sobre como as obras são e o que elas de fato podem (Almeida Salles 2006). Nesse sentido, o "cinema de garagem" brasileiro apontou para outros modelos de produção, com a reorganização das equipes de filmagem em novos arranjos produtivos, menos centrados em modelos industriais de produção (divisão em departamentos, estrutura hierárquica ou verticalizada, como o organograma de uma empresa industrial), mas com a presença de estruturas mais horizontais, ou processos mais coletivos.

A formação de coletivos audiovisuais, como o Alumbramento (CE), Símio (PE), Trincheira (PE) e a Teia (MG), entre outros, ampliou a ecologia da produção audiovisual em distintos modos de fazer, possibilitando a construção de uma "rede de afetos" ou uma "estrutura de sentimentos", como afirma A Nogueira (2014), ao analisar o papel da "brodagem" no cinema pernambucano. A produção em coletivo não anula as singularidades, antes as potencializa. Fazer cinema passa a ser uma experiência, um fenômeno a ser vivido. Viver e criar, criar e viver, passam a se retroalimentar, como parte de um processo orgânico, em que coexistir se torna parte do próprio processo de criação.

Um exemplo típico dessas tendências pode ser visto na produção do Coletivo Alumbramento, sediado em Fortaleza, como nos filmes Estrada para Ythaca (2010) e Os monstros (2011), que assinalam outro arranjo de produção. Quatro membros do coletivo (Guto Parente, Luiz e Ricardo Pretti e Pedro Diógenes) não são apenas os diretores da obra, mas também os roteiristas, fotógrafos, técnicos de som, montadores, e inclusive atores. Ou seja, todas as funções de produção são divididas entre os quatro realizadores, sem hierarquia ou subdivisão de tarefas, conforme a divisão técnica do trabalho (Ikeda 2013). O ponto de partida é serem mais "amigos" que realizam um filme juntos do que "profissionais" que realizam um 
produto midiático. Ademais, o próprio filme incorpora esse sentimento de amizade em sua escritura. Os quatro amigos representam personagens que avançam pelo interior do Ceará em busca dos rastros de um quinto amigo, recentemente falecido. $\mathrm{Ou}$ seja, Estrada para Ythaca é um filme sobre a amizade, feito a partir de uma relação de vivência entre amigos. A amizade, portanto, aos moldes do que propõe Agamben (2009), não é apenas um modo de estar em companhia do outro, mas especialmente de viver e ser junto, ou seja, não é apenas tema do filme, mas a própria argamassa ou combustível que permite que o filme seja feito, não apenas seu olho, mas seu espírito.

Este último ponto possui entrelaçamentos quanto aos aspectos éticos do "cinema de garagem" brasileiro. Buscamos também apontar não apenas para as obras realizadas, mas para uma "rede de afetos" que é construída por meio desses filmes, e também que são geradas pelo próprio processo dos filmes. Ou seja, as obras audiovisuais não devem ser vistas apenas por elas mesmas, como "obras fechadas", mas devem também ser pensadas como gestos. Penso o gesto no sentido flusseriano (Flusser 1994), como exercício sem um fim ou sem um objetivo programático, mas como um movimento no qual se articula uma liberdade. Ver os filmes como um gesto é reconhecer que eles implicam não somente outros modos de fazer, mas principalmente que criam outros modos de ser na sociedade contemporânea. Nesse aspecto, merecem destaque as dramaturgias do comum (Lopes 2012, Prysthon, 2010), a busca por um minimalismo ou uma delicadeza (Lopes 2005), ou ainda as estéticas da frivolidade (Prysthon 2014). São filmes que permitem outra experiência do sensível, outra forma de ser e de estar no mundo, menos regida pelo imediatismo de nossos papeis sociais ou pela mercantilização dos corpos do capitalismo contemporâneo. Se o capitalismo cognitivo busca aproximar trabalho e vida no sentido de se apropriar da liberdade do indivíduo, transformando seu tempo livre em produção de trabalho imaterial, como bem mostram os estudos de biopolítica (Gorz 2005; Lazaratto e Negri 2001; Cocco et alii 2003, na linha de Foucault 1979), essa "rede de afetos" busca, na contramão dessa lógica de intensificação do trabalho contemporâneo, um outro modo de ser e de habitar o mundo.

Esse ponto nos remete diretamente ao quarto eixo: as questões políticas. Pretendemos apontar para filmes que ampliam um cenário de resistência (Camurça 2012), que ofereçam um escape aos modelos de padronização e massificação da sociedade contemporânea, aos processos de globalização, mas articulando esse discurso por meio de uma política das imagens, que possam ir além de uma política com tom de denúncia para propor uma apreensão sensível de uma nova forma de coabitar o mundo a partir das imagens, dialogando com o que propõem autores como DidiHuberman (2011) e Rancière (2005). Nesse sentido, buscamos nos 
aproximar da leitura de Rancière (2012) sobre os filmes de Pedro Costa e de Straub-Huillet, que contribuíram para a proposição de uma outra política dos excluídos, a qual, antes de denunciar ou vitimizar sua condição de explorados, busca "extrair a potência política desses corpos que resistem".

\section{Desafios}

São muitos os desafios para a expansão dessas produções. Esses filmes ainda permanecem pouco vistos, restritos muitas vezes ao circuito dos festivais. A presença do filme estrangeiro em nosso mercado é cada vez mais avassaladora. Um filme como Velozes $e$ Furiosos 8 (2017) chegou a ocupar simultaneamente 1.544 salas de cinema em território nacional (ANCINE 2018). Se aumentam as possibilidades para os nichos de mercado, estes permanecem sendo uma nobre exceção, trincheira de resistência contra o progressivo avanço dos oligopólios globais, das grandes corporações midiáticas que dominam o mercado cinematográfico não apenas do Brasil, mas de boa parte dos países do mundo, inclusive de economias robustas, como a Alemanha e a Itália.

Segundo os relatórios oficiais da Agência Nacional do Cinema (ANCINE 2017), foram lançados 142 filmes brasileiros nas salas de cinemas em 2016. Se o número de filmes lançados é expressivo, os dados mascaram outra realidade. Enquanto seis filmes ultrapassaram a marca de um milhão de espectadores, a grande maioria dos filmes brasileiros permanece sendo pouco vista. Entre os 142 filmes, 94 (66,2\%) não atingiram 10 mil espectadores e 43 filmes (ou 30,3\%), menos de mil espectadores. Ou seja, dois em cada três filmes brasileiros lançados não atingiram um público de dez mil espectadores nas salas de cinema.

Esse dado comprova uma tendência do mercado cinematográfico, acentuada com o multiplex: a concentração das receitas de bilheterias em um número cada vez menor de filmes. $\mathrm{O}$ modelo de exibição consagrado mundialmente aprofundou ainda mais o domínio das majors. Ainda que a geração do "cinema de garagem" tenha, cada vez mais, atingido uma legitimidade simbólica, com a presença e premiações nos principais festivais nacionais e internacionais, esses filmes não conseguem atingir o grande público.

Ao mesmo tempo, é preciso que os cineastas busquem caminhos alternativos para a exibição de seus filmes, otimizando os nascentes nichos de mercado, e explorando alternativas mais ousadas de distribuição de seus filmes. O potencial da Internet, assim como dos canais de video-sob-demanda, dos conteúdos para celular e demais aparelhos portáteis, permanece muito pouco utilizado pelo audiovisual brasileiro. A tendência mundial é a de personalização dos formatos e dos dispositivos, migrando para a flexibilização dos produtos. $\mathrm{O}$ consumidor quer poder ver o que quiser, quando quiser $\mathrm{e}$ 
onde puder. A era da TV aberta, em que um emissor irradiava o mesmo sinal para milhões de receptores, sintonizados num mesmo horário, presos a uma grande de programação, parece ter os dias contados. O conteúdo sob demanda favorece a flexibilidade de formatos, horários e dispositivos típicos do mundo contemporâneo, como se o audiovisual fosse uma das janelas que o consumidor tem acessível ao alcance de seus olhos, ou de um simples clique (Luca 2009).

Os realizadores audiovisuais brasileiros parecem ainda pouco atentos às possibilidades efetivas que as transformações nos modos de recepção podem oferecer para o audiovisual brasileiro independente. Ainda perseguem um modelo de produção e de distribuição tradicional, em que visam os segmentos de mercado mais tradicionais: cinema (festivais de cinema, e depois circuito comercial) e televisão (fechada e aberta). Se houve indiscutíveis avanços nos modelos de produção e no circuito simbólico de difusão (mostras e festivais de cinema), os modelos de distribuição desses filmes permanecem muito próximos aos padrões tradicionais, seguindo a exibição escalonada nos sucessivos segmentos de mercado.

\section{BIBLIOGRAFIA}

Abreu, Nuno César de. 2006. Boca do lixo: cinema e classes populares. Campinas: UNICAMP.

Agamben, Giorgio. 2009. O que é o contemporâneo? e outros ensaios. Chapecó: Editora Argos.

Alcoforado, Fernando. 1998. De Collor a FHC: o Brasil e a nova (des) ordem mundial. São Paulo: Nobel.

Almeida, Paulo Sérgio; Butcher, Pedro. 2003. Cinema, desenvolvimento e mercado. Rio de Janeiro: BNDES/Aeroplano.

Almeida, Rodrigo; Mendonça, Fernando. 2012. "O cinema pernambucano entre gerações". In Cinema de garagem: panorama da produção brasileira independente do novo século, organizado por Marcelo Ikeda e Dellani Lima. Rio de Janeiro: WSET Multimídia.

Almeida Salles, Cecília. 2006. Redes da criação: construção da obra de arte. São Paulo, ed. Horizonte.

ANCINE. 2017. Anuário Estatístico do Cinema Brasileiro 2016. Rio de Janeiro: ANCINE.

https://oca.ancine.gov.br/sites/default/files/repositorio/pdf /anuario_2016.pdf. Acessado em 02/07/2018. 
ANCINE. 2018. Segmento de Salas de Exibição - Informe Anual Preliminar 2017. Rio de Janeiro: ANCINE. https://oca.ancine.gov.br/sites/default/files/repositorio/pdf /informe_preliminar_2017_0.pdf. Acessado em 02/07/2018.

Antunes, Ricardo 2004. A desertificação neoliberal no Brasil. Campinas: Autores Associados.

Azevedo, Anna Maria de. 2014. "A potência da imagem-ruína na poética do cinema.” Dissertação de Mestrado. Departamento de Comunicação Social, Pontifícia Universidade Católica do Rio de Janeiro. Rio de Janeiro.

Bahia, Lia. 2009. "Uma análise do campo cinematográfico sob a perspectiva industrial.” Dissertação de Mestrado. Programa de Pós-Graduação em Comunicação, Universidade Federal Fluminense. Niterói.

Bezerra, Julio. 2010. "O corpo como cogito: um cinema contemporâneo à luz de Merleau-Ponty”. E-Compós, 13 (1). http://www.e-compos.org.br/ecompos/article/viewFile/476/422. Acessado em 02/07/2018.

Bordwell, David. 2005. "O cinema clássico hollywoodiano: normas e princípios narrativos”. In Teoria contemporânea do cinema, vol. II, editado por Fernão Ramos. São Paulo: Editora Senac.

Camurça, Rodrigo Capistrano. 2012. "Formas de resistência: o documentário contemporâneo cearense." Dissertação de Mestrado. Programa de Pós-Graduação em Comunicação, Universidade Federal Fluminense. Niterói.

Catani, Afrânio Mendes. 1994. "Política cinematográfica nos anos Collor (1990-1992): um arremedo neoliberal”. Revista Imagens, $\mathrm{n}^{\circ}$ 3. Campinas: Editora da UNICAMP.

Cocco, Giuseppe; Galvão, Alexander Patez; Silva, Gerardo (orgs). 2003. Capitalismo cognitivo. Rio de Janeiro: DP\&A editora.

Comolli, Jean-Louis 2008. Ver e poder: a inocência perdida - cinema, televisão, ficção, documentário. Belo Horizonte: Ed. UFMG.

Costa, Bruno. 2009. "Práticas autobiográficas contemporâneas: as videografias de si”. Doc On-line, n.06. http://www.doc.ubi.pt/06/artigo_bruno_costa.pdf. Acessado em 02/07/2018.

Didi-Huberman, Georges. 2011. Sobrevivência dos vagalumes. Belo Horizonte: Editora UFMG.

Feldman, Ilana. 2012. "Jogos de cena: ensaios sobre o documentário brasileiro contemporâneo." Tese de Doutorado. Programa de Pós-Graduação em Ciências da Comunicação, Universidade de São Paulo. 
Flusser, Vilém. 1994. Los gestos. Fenomenología y comunicación. Barcelona: Herder.

Foucault, Michel. 1979. Microfísica do poder. Rio de Janeiro: Graal.

Gatti, André. 2005. "Distribuição e exibição na indústria cinematográfica brasileira (1993-2003).” Tese de Doutorado. Programa de Pós-Graduação em Multimeios, Universidade de Campinas.

Gorz, André. 2005. O imaterial. São Paulo: Annablume.

Ikeda, Marcelo e Dellani Lima (orgs.). 2011. Cinema de garagem - um inventário afetivo sobre o jovem cinema brasileiro do século XXI. Belo Horizonte/Fortaleza: Suburbana Co.

-_- 2012. Cinema de garagem: panorama da produção brasileira independente do novo século. Rio de Janeiro: WSET Produções.

-_- 2014. Cinema de garagem 2014. Rio de Janeiro: WSET Produções.

Ikeda, Marcelo. 2012. "O nevoeiro, provisoriamente". In Cinema de garagem: panorama da produção brasileira independente do novo século, organizado por Marcelo Ikeda e Dellani Lima. Rio de Janeiro: WSET Produções.

-_- 2013. "Novas tendências no cinema contemporâneo brasileiro e o Coletivo Alumbramento" In Cinema(s) independente(s): cartografias para um fenômeno audiovisual global, organizado por Alfredo Suppia. Juiz de Fora: Editora UFJF.

——- 2014. O cinema de garagem: desafios e apontamentos para uma curadoria em construção. In Cinema de garagem, organizado por Marcelo Ikeda e Dellani Lima. Rio de Janeiro: WSET Produções.

—_- 2015. Cinema brasileiro a partir da retomada: aspectos econômicos e políticos. São Paulo: Editora Summus.

Klinger, Diana. 2006. "Escritas de si, escritas do outro." Tese de Doutorado em Letras. Programa de Pós-Graduação em Letras, UERJ.

Lazzarato, Maurizio; Negri, Antonio. 2001. Trabalho imaterial. Rio de Janeiro: DP\&A Editora.

Leal, Antonio e Mattos, Tetê. 2008. Festivais audiovisuais: Diagnóstico Setorial 2007/indicadores 2006. Rio de Janeiro: Fórum dos Festivais.

http://www.cultura.gov.br/documents/10877/35301/diag07 -indic06-ok.pdf/3a88e775-3a64-47c7-b650-0010d8e9f6ff. Acessado em 02/07/2018. 
Lins, Consuelo, e Claudia Mesquita. 2008. Filmar o real: sobre o documentário brasileiro contemporâneo. Rio de Janeiro: Jorge Zahar Ed.

Lopes, Denilson. 2005. A delicadeza: estética, experiência e paisagens. Brasília, Ed. UnB.

———. 2012. No coração do mundo: paisagens transculturais. Rio de Janeiro: Rocco.

Lopes, Denise. 2001. “Cinema brasileiro pós-Collor.” Dissertação de Mestrado. Programa de Pós-Graduação em Comunicação, Universidade Federal Fluminense. Niterói.

Luca, Luiz Gonzaga Assis. 2009. A hora do cinema digital. São Paulo, Imprensa Nacional.

Lyra, Bernardette. 2009. "Cinema periférico de bordas". Comunicação, mídia e consumo 6 (15). http://revistacmc.espm.br/index.php/revistacmc/article/vie $\mathrm{w} / 145$. Acessado em 02/07/2018.

Lyra, Bernardette, e Gelson Santana (orgs.). 2006. Cinema de bordas. São Paulo: A Lápis.

Machado, Arlindo. 2003. Made in Brasil: três décadas do vídeo brasileiro. São Paulo: Itaú Cultural.

Marson, Melina. 2006. "O cinema da retomada: Estado e cinema no Brasil da dissolução da Embrafilme à criação da ANCINE." Dissertação de Mestrado. Programa de Pós-Graduação em Sociologia, Universidade de Campinas.

Migliorin, Cezar (org.). 2010. Ensaios no real - o documentário brasileiro hoje. Rio de Janeiro: Azougue Editorial.

———. 2011. "Por um cinema pós-industrial: notas para um debate". Revista Cinética. http://www.revistacinetica.com.br/cinemaposindustrial.htm. Acessado em 02/07/2018.

Moraes, Dênis de. 2006. Sociedade midiatizada. Rio de Janeiro: Mauad.

Nichols, Bill. 2005. Introdução ao Documentário. Campinas: Papirus.

Nogueira, Cynthia. 2006. "Anos 90, anos 60: a crítica cinematográfica brasileira "pós-retomada" e a tradição moderna." Dissertação de Mestrado. Programa de Pós-Graduação em Comunicação, Universidade Federal Fluminense.

Nogueira, Amanda Mansur Custódio. 2014. "A Brodagem no cinema em Pernambuco." Tese de Doutorado. Programa de PósGraduação em Comunicação, Universidade Federal de Pernambuco. 
Oliveira Jr., Luiz Carlos. 2013. A mise en scène no cinema: do clássico ao cinema de fluxo. Campinas: Papirus.

Prysthon, Angela. 2002. Cosmopolitismos periféricos: ensaios sobre modernidade, pós-modernidade e estudos culturais na América Latina. Recife: Bagaço.

—_- 2010. "O real e o banal no cinema pernambucano contemporâneo". In Actas del II Congreso de ASAECA Buenos Aires. http://www.asaeca.org/aactas/prysthon_angela.pdf. Acessado em 02/07/2018.

—_- 2013. "Transformações da crítica diante da cibercinefilia”. Celeuma 1 (1).

http://www.revistas.usp.br/celeuma/article/view/68021/70 591. Acessado em 02/07/2018.

———. 2015. "Furiosas frivolidades: artifício, heterotopias e temporalidades estranhas no cinema brasileiro contemporâneo". Revista Eco-Pós (Online), 18 (3). https://revistas.ufrj.br/index.php/eco_pos/article/view/276 3. Acessado em 02/07/2018.

Rancière, Jacques. 2005. A partilha do sensível: estética e política. São Paulo: Editora 34.

-_- 2012. "Política de Pedro Costa". In As distâncias do cinema. Rio de Janeiro: Contraponto.

Rosenbaum, Jonathan, e Adrian Martin. 2003. Movie mutations: the changing face of world cinephilia. Londres: British Film Institute.

Santos, Milton. 2000. Por uma outra globalização: do pensamento único à consciência universal. Rio de Janeiro, Record.

Selonk, Aleteia. 2004. "Distribuição cinematográfica no Brasil e suas repercussões políticas e sociais: um estudo comparado da distribuição da cinematografia nacional e estrangeira." Dissertação de Mestrado. Programa de Pós-Graduação em Comunicação, Pontifícia Universidade Católica do Rio Grande do Sul.

Shaviro, Steven. 1993. The cinematic body. London/Minneapolis: University of Minnesota Press.

Simões, Inimá. 2007. "Sexo à brasileira”. Alceu 8 (15). http://revistaalceu.com.pucrio.br/media/Alceu_n15 Simoes.pdf. Acessado em 02/07/2018.

Vieira Jr., Luiz Garcia. 2011. Filmes found footage: fragmento $e$ heterogêneos no laboratório da vanguarda. Niterói: Dissertação 
de Mestrado. Programa de Pós-Graduação em Comunicação, Universidade Federal Fluminense.

Whitaker, Guilherme. 2011. "Sessão Incinerasta”. In MFL 2011: 10 Mostra do Filme Livre, organizado por Guilherme Whitaker.

Rio de Janeiro: WSET Multimídia.

http://www.bb.com.br/docs/pub/inst/dwn/CatalogoMFL20 11.pdf. Acessado em 02/07/2018.

Recebido em 15-01-2018. Aceite para publicação em 17-06-2018. 